\title{
Seasonality effects over the ecological aquaculture of the native zooplanktivorous fish from South America Odontesthes bonariensis
}

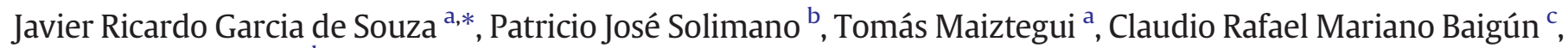 \\ María Cristina Claps ${ }^{\mathrm{d}}$, Darío César Colautti ${ }^{\text {a }}$ \\ a Instituto de Limnología “Dr. Raúl A. Ringuelet” (ILPLA, CONICET-UNLP). Laboratorio de Ecología de Peces, Boulevard 120 y 62, N¹460, CC: 712, CP: 1900 La Plata, Buenos Aires, Argentina \\ b Escuela de producción, tecnología y medio ambiente. Universidad Nacional de Rio Negro. Sede Atlántica, Av. Don Bosco y Leloir s/n, Viedma CP.8500, Argentina

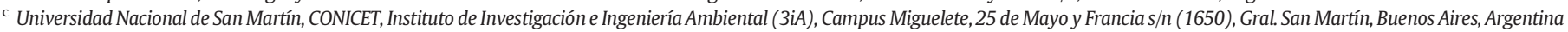 \\ d Instituto de Limnología “Dr. Raúl A. Ringuelet" (ILPLA, CONICET-UNLP). Laboratorio de Cuenca del Salado, Boulevard 120 y 62, N¹460, CP: 1900 - CC: 712 La Plata, Buenos Aires, Argentina
}

\section{A R T I C L E I N F O}

\section{Article history:}

Received 26 April 2016

Received in revised form 30 December 2016

Accepted 3 January 2017

Available online 05 January 2017

\section{Keywords:}

Ecological aquaculture

Pejerrey

Pampean lakes

Cage culture

\begin{abstract}
A B S T R A C T
Ecological aquaculture systems consider the natural and social environments in which they are situated in the search to contribute to environmental sustainability. In South America, the aquaculture of the native zooplanktivorous fish Odontesthes bonariensis ("pejerrey") has some constraints that could be overcome by applying extensive culture systems following an ecosystemic approach. This study represents the first attempt to develop ecological aquaculture in the region. An experiment of extensive cage culture was carried out in La Salada de Monasterio Lake to answer how seasonal changes, both in physico-chemical and zooplankton features, affect the performance of pejerrey culture. Three successive rearing trials were carried out in spring, summer and autumn. The cages were stocked with pejerrey; whereas others (controls) were left without fish. Lake zooplankton abundance, biomass and species composition were different among seasons, with maximum abundance mean values during summer and maximum biomass mean values during spring. The zooplankton abundance found in cages without fish was higher than that registered in cages with fish, but no differences in species composition among those cages were detected. The pejerrey showed selective feeding habits throughout the entire experiment, and they fed mostly on copepods and cladocerans of $>0.7 \mathrm{~mm}$ during spring and summer, especially after reaching $4 \mathrm{~cm}$ in total length, and on smaller copepods and cladocerans during autumn. The contribution of the different sizes of zooplankton to the gut contents was related to availability and to fish size, and the access to bigger zooplankton appeared to be a critical factor to promote better growth performance. The bigger fish were obtained in spring, when zooplankton biomass was maximum in the lake with greater representation of large cladocerans, with final fish weight eight times higher than that obtained in summer and fifty times greater than that obtained in autumn. The production obtained in spring was one and two orders of magnitude higher than that found in summer and autumn. The multiple linear regressions selected support the inference that seasonal temperature and zooplankton variations have effects on pejerrey growth in floating cages. Pampean lakes could be suitable environments to support pejerrey ecological aquaculture, and spring emerges as the better season to start an extensive culture that takes advantage of the zooplankton composition and dynamics.

Statement of relevance to commercial aquaculture: Alternative tool to overcome constraints in pejerrey culture.
\end{abstract}

(c) 2017 Elsevier B.V. All rights reserved.

\section{Introduction}

Ecological aquaculture incorporates the development of aquatic farming systems that preserve and enhance the forms and functions of the natural and social environments in which they are situated (Costa-

\footnotetext{
* Corresponding author.

E-mail addresses: javiergds@ilpla.edu.ar (J.R. Garcia de Souza),psolimano@unrn.edu.ar (P.J. Solimano), maiztegui@ilpla.edu.ar (T. Maiztegui), cbaigun@gmail.com (C.R.M. Baigún), claps@ilpla.edu.ar (M.C. Claps), colautti@ilpla.edu.ar (D.C. Colautti).
}

Pierce, 2002). This approach has the aim to develop linkages among aquaculture, the environment and society to promote complementary roles and contribute to environmental sustainability, rehabilitation and enhancement (Hambrey et al., 2008).

Freshwater cage aquaculture has been implemented in the production of many fish species worldwide (Beveridge, 2004). Extensive production in cages allows those involved to achieve low-cost results in productive environments rearing fish species that feed on the lower levels of the food chain (Little and Muir, 1987). This technique has been found highly dependent on environmental characteristics, mainly due to the dependence of primary production on the availability of 
nutrients, light and temperature (Le Cren and Lowe-McConnell, 1980; OECD, 1982; Beveridge, 2004). It is possible to take advantage of the exceptionally high natural productivity exhibited by most of Pampean lakes (Colautti et al., 2010; Diovisalvi et al., 2015b) by extensive cage culture systems. These lakes have higher total phosphorous and chlorophyll $a$ and much lower transparency than temperate lakes from the Northern Hemisphere (Diovisalvi et al., 2015b).

Pejerrey (Odontesthes bonariensis) is the most important fishing resource in shallow lakes and reservoirs in Argentina (Baigún and Anderson, 1994). This zooplanktivorous species (Destefanis and Freyre, 1972; Ringuelet et al., 1980; Freyre et al., 2009) is well represented in Pampean shallow lakes. The development of intensive culture techniques for the species started in the early twentieth century (Somoza et al., 2008). In recent years, it has been possible to successfully complete production in tanks (Velasco et al., 2008; Berasain et al., 2015). According to Somoza et al. (2008), factors from biological nature, techno-scientific knowledge gaps and also cultural or socio-economic features have contributed to the historical stagnation of pejerrey-intensive aquaculture development in Argentina. Although eggs and larvae can be produced in a massive way, one of the main constraints is the acquisition of large numbers of juveniles for stocking or fattening. To achieve success in aquaculture, it is necessary to consider the "critical period" (sensu Hjort, 1914) of the first feeding stages (Atencio-García et al., 2003a; Prieto Guevara et al., 2006) and understand how the environmental characteristics relate to the feeding habits of fish. In fact, the feeding and nutrition of fish post-larvae could represent a bottleneck that prevents expansion of the activity (Prieto Guevara and AtencioGarcía, 2008) as occurs with pejerrey. In this context, extensive cage culture has been envisioned as an alternative tool to overcome some of the current constraints, and it has been successfully applied for juvenile pejerrey production in Pampean shallow lakes (Colautti et al., 2009; Colautti et al., 2010; Solimano et al., 2015; Garcia de Souza et al., 2015).

Pampean lakes are typically shallow and eutrophic aquatic systems (Quirós and Drago, 1999; Escalante, 2001; Quirós et al., 2002; Claps et al., 2004), which display remarkable seasonal environmental dynamics (Diovisalvi et al., 2015a). Such variability is reflected by fluctuations in physical and chemical features (Pérez et al., 2011; Lagomarsino et al.,
2011) and primary production (Torremorell et al., 2007, 2009), thus shaping the ecosystem processes and community structure. In these lakes, the structure and abundance of the zooplankton community are regulated not only by the mentioned factors (Benítez and Claps, 2000; Solari et al., 2002; González Sagrario et al., 2009; Diovisalvi et al., 2010) but also highly affected by fish planktivory (Diovisalvi et al., 2015a). Therefore, the implementation of a successful extensive or even semi-extensive pejerrey culture in Pampean lakes requires an understanding of qualitative and quantitative annual changes in the zooplankton assemblage together with pejerrey ecological characteristics. This species exhibits a high dependence on zooplankton abundance, which influences their body condition and growth, not only in wild populations (Colautti et al., 2003; Freyre et al., 2009) but also in the context of extensive aquaculture in floating cages (Garcia de Souza et al., 2015). For instance, Colautti et al. (2010) found that the highest growth rates for pejerrey cultured in floating cages in Lacombe Lake were associated with warmer temperatures in spring and summer and also with seasonal abundance peaks of the major groups of zooplankton, e.g., copepods and cladocerans. Velasco et al. (2008) observed maximum growth rates during the summer months among pejerrey larvae fed with zooplankton and artificial food under intensive conditions. This implies that the successful culture of pejerrey in temperate shallow lakes should consider thermal patterns as well as food quality and availability. In addition, it is important to consider that in pejerrey wild populations, spawning events start in late winter, peaking in spring and extending to autumn (Miranda et al., 2006; Elisio et al., 2012; Elisio et al., 2015), indicating that this period of the year is the most appropriate to promote the performance of the new cohorts. Accordingly, it is highly probable that the birth of larvae overlaps with plankton blooms as predicted by the match-mismatch hypothesis (Cushing, 1972, 1990). Therefore, in extensive cage culture, it could be very important to consider the timing of introducing the fish to the cages, to understand how to take advantage of the natural production cycle of zooplankton and optimize this culture technique.

Hence, in order to generate suitable guidelines to develop an ecological aquaculture for pejerrey in Pampean lakes, the objectives of this study are to understand how seasonal changes in physical and chemical

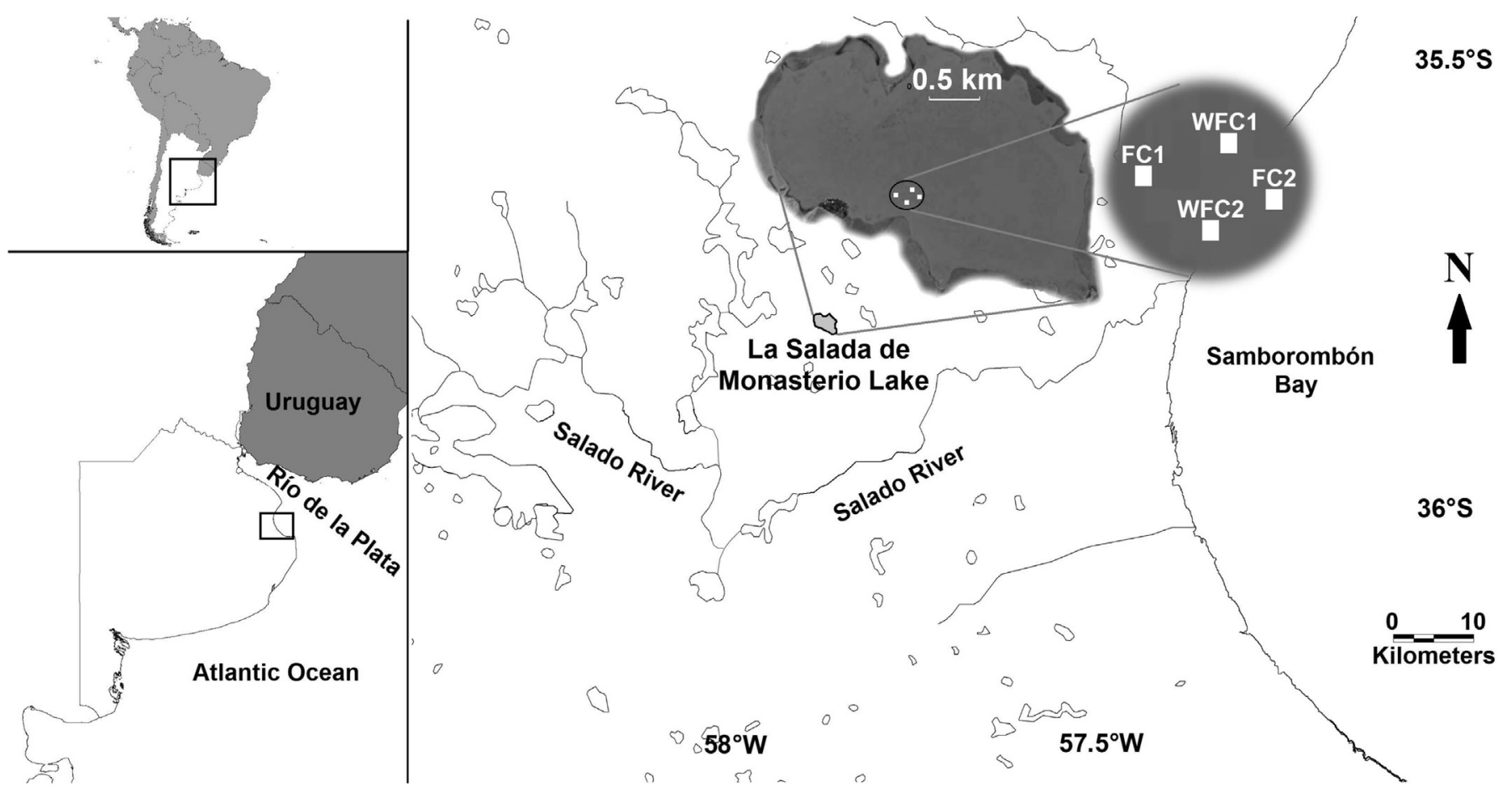

Fig. 1. Geographical position of "La Salada de Monasterio" Lake in Argentina and locations of floating cages used in the experiment. 
Table 1

Physical and chemical parameters: mean values obtained during the three trials on every sampling date.

\begin{tabular}{|c|c|c|c|c|c|c|c|}
\hline & Date & Depth (m) & Transparency (Secchi m) & Conductivity $\left(\mathrm{mS} \mathrm{cm}^{-1}\right)$ & $\mathrm{pH}$ & Dissolved oxygen $\left(\mathrm{mg} \mathrm{L}^{-1}\right)$ & $\begin{array}{l}\text { Oxygen saturation } \\
\text { percentage (\%) }\end{array}$ \\
\hline \multirow[t]{5}{*}{ Experiment 1: Spring } & 24 October 2008 & 1.70 & 0.20 & 1.35 & 8.4 & 10.4 & 125 \\
\hline & 11 November 2008 & 1.70 & 0.22 & 1.06 & 8.6 & 8.8 & 105 \\
\hline & 21 November 2008 & 1.70 & 0.30 & 1.12 & 8.4 & 9.2 & 112 \\
\hline & 02 December 2008 & 1.40 & 0.42 & 1.26 & 8.4 & 8.4 & 95 \\
\hline & 17 December 2008 & 1.40 & 0.35 & 1.24 & 8.4 & 7.8 & 96 \\
\hline \multirow[t]{5}{*}{ Experiment 2: Summer } & 08 January 2009 & 1.35 & 0.35 & 1.34 & 8.8 & 9.7 & 117 \\
\hline & 05 February 2009 & 1.20 & 0.43 & 1.43 & 8.9 & 8.0 & 95 \\
\hline & 13 February 2009 & 1.20 & 0.40 & 1.36 & 8.2 & 9.1 & 101 \\
\hline & 11 March 2009 & 1.20 & 0.32 & 1.71 & 8.9 & 8.0 & 95 \\
\hline & 30 March 2009 & 1.05 & 0.31 & 1.76 & 9.1 & 8.3 & 95 \\
\hline \multirow[t]{6}{*}{ Experiment 3: Autumn } & 08 June 2009 & 0.90 & 0.25 & 1.78 & 9.0 & 10.4 & 110 \\
\hline & 17 June 2009 & 0.90 & 0.24 & 1.79 & 9.0 & 9.4 & 96 \\
\hline & 02 July 2009 & 0.90 & 0.20 & 1.80 & 9.3 & 10.2 & 100 \\
\hline & 17 July 2009 & 1.00 & 0.21 & 1.79 & 9.1 & 13.3 & 140 \\
\hline & 30 July 2009 & 1.05 & 0.15 & 1.69 & 9.0 & 10.5 & 98 \\
\hline & 06 August 2009 & 1.05 & 0.15 & 1.69 & 9.0 & 10.8 & 110 \\
\hline
\end{tabular}

features and in zooplankton assemblage affect post-larval survival and growth in extensive culture systems, and how the structure of this community is modulated by pejerrey predation.

\section{Materials and methods}

\subsection{Study area}

The study was conducted in a shallow lake in the Pampean region of Argentina, called La Salada de Monasterio ( $35^{\circ} 47^{\prime}$ S, $57^{\circ} 52^{\prime}$ W). It has an area of approximately 600 ha and $1.3 \mathrm{~m}$ of mean depth, and it is covered with abundant patches of rooted emergent vegetation (Scirpus californicus), with moderate agricultural activity and extensive cattle rearing in the surrounding areas (Fig. 1).

\subsection{Experimental design}

As species spawning events can occur from spring to autumn, an experiment consisting of three successive rearing trials (T1, T2 and T3) was conducted in spring, summer and autumn of 2008 and 2009. In each season, four floating cages of $12 \mathrm{~m}^{3}$ each (FC1 to FC4), were stocked with post-larval pejerrey (of around $2 \mathrm{~cm}$ in total length) previously reared in experimental ponds from hatching. The cage design was the same as expounded in Colautti et al. (2010) with a $4 \times 4 \mathrm{~m}$ floating wooden frame, to which one net bag of $1.4 \mathrm{~m}$ height ( $1 \mathrm{~m}$ effectively submerged) was added around the inner perimeter $(3.5 \times 3.5 \mathrm{~m})$.

The cages were installed in a plant-free zone of approximately 3 ha, leaving approximately $75 \mathrm{~m}$ between them. Two were stocked with 500 juveniles of pejerrey each, at a density of 42 ind $\cdot \mathrm{m}^{-3}$ (FC1 and FC2), and two were left without fish (WFC1 and WFC2) and considered as controls. For the first two trials (T1 and T2), the cages were stocked with pejerrey of 26 days old, starting dates October 22 and January 12 , respectively. The autumn trial (T3) started with fish of 45 days-old in June 8 , because it took longer to reach the size of around $2 \mathrm{~cm}$ in the ponds. The fish reared in spring were born on September 26, those reared in summer on December 17 , and the ones reared in autumn on April 24. Thus, a mixed two-factor experimental design, with "time" as an intra-subject factor and "season" as the inter-subject factor, was conducted. The trials lasted until the fish reached 104 days old.

\subsection{Monitoring and analysis of samples}

Mean daily water temperature, depth and conductivity were obtained every hour with two programmable automatic thermo-loggers (Solinst Levelogger, Georgetown, Canada), installed close to the cages. Transparency and pH were measured weekly using a Secchi disk and a

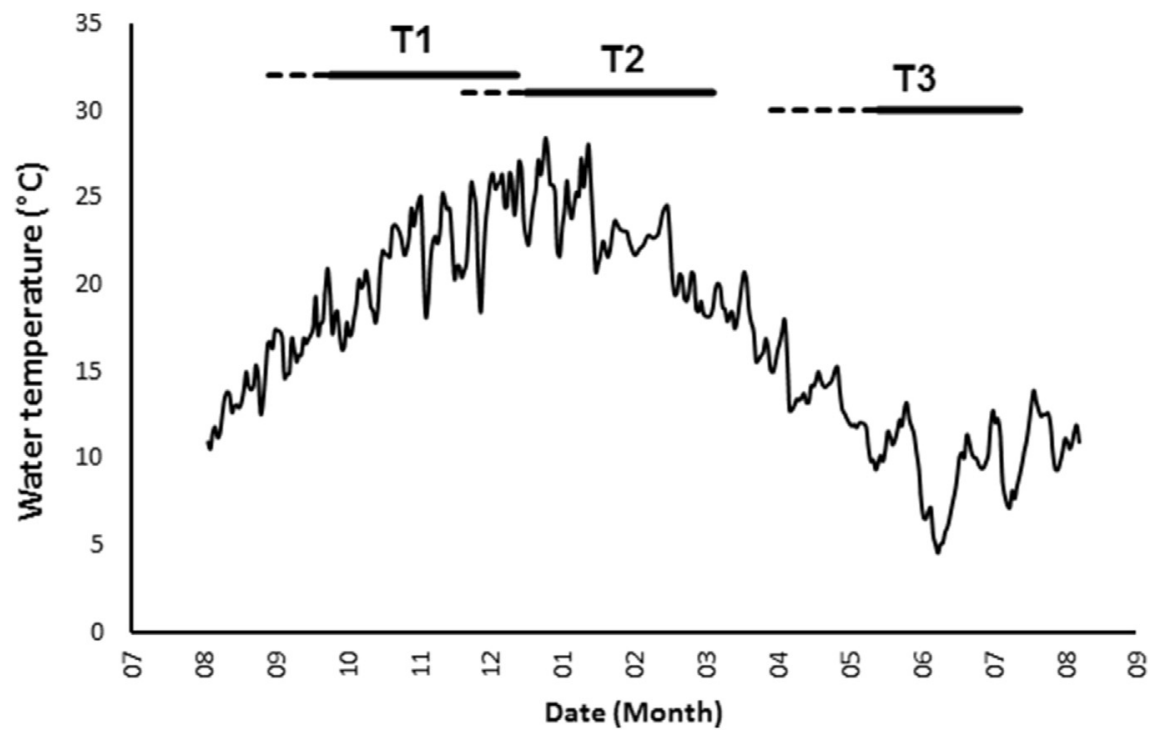

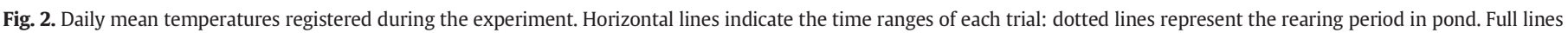
indicate the period of extensive culture in cages in the lake. 
ĐRotifera $\square$ Nauplii Larvae $⿴$ Cyclopoida Copepoda 图 Cladocera

T1

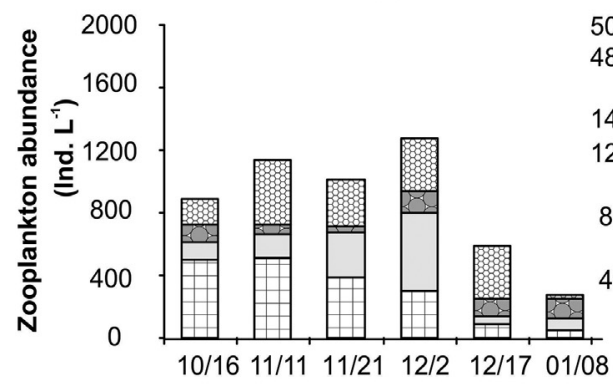

T2

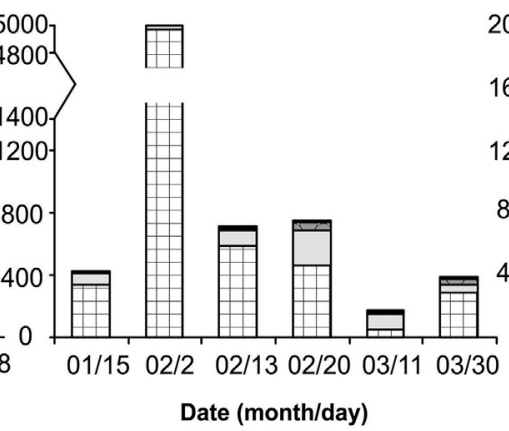

T3

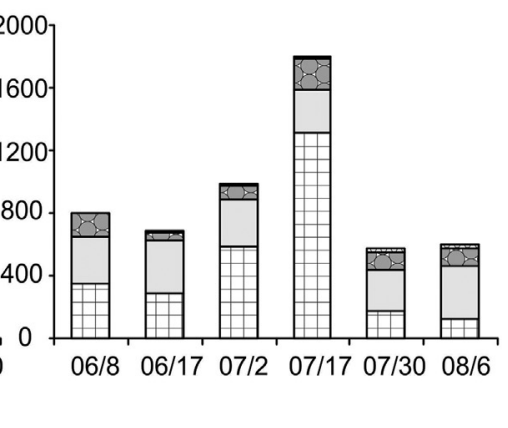

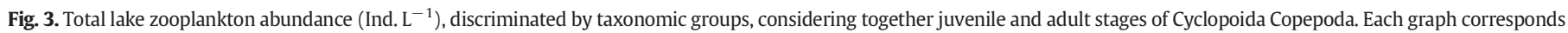
with each season trial (T1, T2 and T3).

multi parameter sensor (Hanna HI 98130; Smithfield, RI, USA), respectively. Zooplankton was sampled fortnightly inside and outside the experimental units, through a submergible suction pump, starting one week before the fish were stocked in their respective treatments. The sampling sites inside the cages were in the middle of those, while outside the cages the zooplankton samples were taken approximately three meters upwind of the FC cages.

At each sampling site, $60 \mathrm{~L}$ of water was taken as follows: 20 L near the lake or cage bottom, $20 \mathrm{~L}$ at an intermediate depth, and $20 \mathrm{~L}$ close to the surface. The three depths were integrated in one sample representing the whole water column, filtered through a plankton net of $50-\mu \mathrm{m}$ mesh size and fixed in $4 \%$ formalin. The samples were analysed qualitatively and quantitatively in Sedgwick-Rafter (APHA, 1995) and Bogorov (Gannon, 1971) counting chambers. The zooplankton members were identified to genus or species level and counted to estimate their abundance per litre (ind $\cdot \mathrm{L}^{-1}$ ) inside the cages and outside the cages. At least 20 individuals of each species per sample were measured to obtain an estimate of their size (length). The zooplankton components were grouped in three size classes: I, up to $0.3 \mathrm{~mm}$ (rotifers and nauplii larvae of copepods); II, 0.3-0.7 mm (small copepods and cladocerans); III: $>0.7 \mathrm{~mm}$ (large copepods and cladocerans). Zooplankton mean size at each sampling date and treatment was estimated as the average of mean value of each size class according to its respective abundance. Dry weights of the zooplankton components were estimated for each sampling date and for each treatment. In the case of the rotifers, these were estimated from volume measurements using geometric approximations (Ruttner-Kolisko, 1977; McCauley, 1984). For the microcrustaceans, estimates were made from length-weight regressions available for similar species (Dumont et al., 1975; Bottrell et al., 1976;

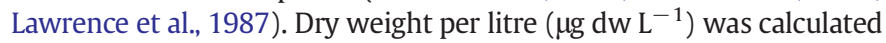
for zooplankton inside and outside the cages.

The reared fish were sampled monthly, starting 1 week after they were stocked. In each sampling date, 15 individuals per cage were anaesthetised ( $10 \mathrm{~mL}$ of benzocaine solution [ $1 \mathrm{~g}$ : $100 \mathrm{~mL}$ alcohol] in $1000 \mathrm{~mL}$ of water) and were measured in length in situ (total length in $\mathrm{cm}$ ). Another five fish were slaughtered in ice to avoid food

Table 2

Pair-wise comparisons of lake zooplankton abundance among trials (T1, T2 and T3) (SIMPER).

\begin{tabular}{|c|c|c|c|}
\hline & T1 vs. T2 & T1 vs. T3 & T2 vs. T3 \\
\hline Dissimilarity (\%) & 49.04 & 42.80 & 54.20 \\
\hline $\begin{array}{l}\text { Discriminant } \\
\text { species }^{\mathrm{a}}\end{array}$ & $\begin{array}{l}\text { Ceriodaphnia cf. dubia } \\
\text { (> in T1) and } \\
\text { Brachionus havanaensis } \\
(>\text { in } \mathrm{T} 2)\end{array}$ & $\begin{array}{l}\text { Ceriodaphnia } \\
\text { cf. dubia and } \\
\text { Polyarthra vulgaris } \\
\text { (> in } \mathrm{T} 1 \text { ) }\end{array}$ & $\begin{array}{l}\text { Brachionus } \\
\text { havanaensis } \\
\text { (> in T2) and } \\
\text { Keratella tropica } \\
\text { (> in T3) }\end{array}$ \\
\hline
\end{tabular}

\footnotetext{
a Only species contributing $>10 \%$ of overall dissimilarity are reported.
}

regurgitation and were carried to the laboratory where they were measured and weighed (total weight in $g$ ), then fixed in $10 \%$ formalin for subsequent dietary analysis. The gut contents of the first two-thirds of the digestive tract were transferred to counting chambers and treated as described above for zooplankton samples. At the end of the trials, all fish in each cage were counted.

\subsection{Data analysis}

\subsubsection{Zooplankton community (natural food supply)}

To test if zooplankton structure differed among seasons and between and within FC, WFC and lake, ANOSIM (non-parametric analysis, permutation-based one-way ANOSIM) was applied (Clarke and Warwick, 2001). Similarity percentages (SIMPER) were used to identify the species ("discriminating species") that were most important to account for the observed similarity (or dissimilarity) between samples. The method uses the Bray-Curtis measure of similarity, comparing in turn each sample in one group with each sample in another. Prior to both analyses, the rare species were discarded from the general matrix; then the data were transformed to $\log (x+1)$ to reduce the contribution of highly abundant species.

\subsubsection{Feeding of cultured pejerrey}

The data about the specimens found in the gut contents were treated as those from the zooplankton samples, and prey mean size $(\mathrm{mm})$ was calculated. The relative abundance of zooplankton ingested was analysed together with the relative abundance of zooplankton found in the environment using ANOSIM and SIMPER to evaluate the differences and similarities between what was offered by the environment (natural food supply) and what was consumed by fish.

In order to have a more realistic idea of the food supply, and taking into account that the samples of zooplankton were collected more frequently than the fish samples, zooplankton abundance was normalized for each fish sampling period to relate this value with the species ingested by fish. Normalization was performed as follows: first, partial mean zooplankton abundances between successive sampling dates were calculated, then these values were multiplied by the number of days that had passed from the beginning of each period considered, and finally, these partial mean abundances were averaged considering the total number of days of the period between the successive fish samplings.

In turn, the food selectivity of the reared fish at each age and trial was evaluated applying the foraging rate food selectivity index (FR):

$\mathrm{FR}=\mathrm{pC}_{\mathrm{i}} * \mathrm{pO}_{\mathrm{i}}^{-}{ }^{-}$

where $\mathrm{pC}_{\mathrm{i}}$ is the proportion of each zooplankter in relation to the total number of individuals consumed by fish, and $\mathrm{pO}_{\mathrm{i}}$ is the proportion of 


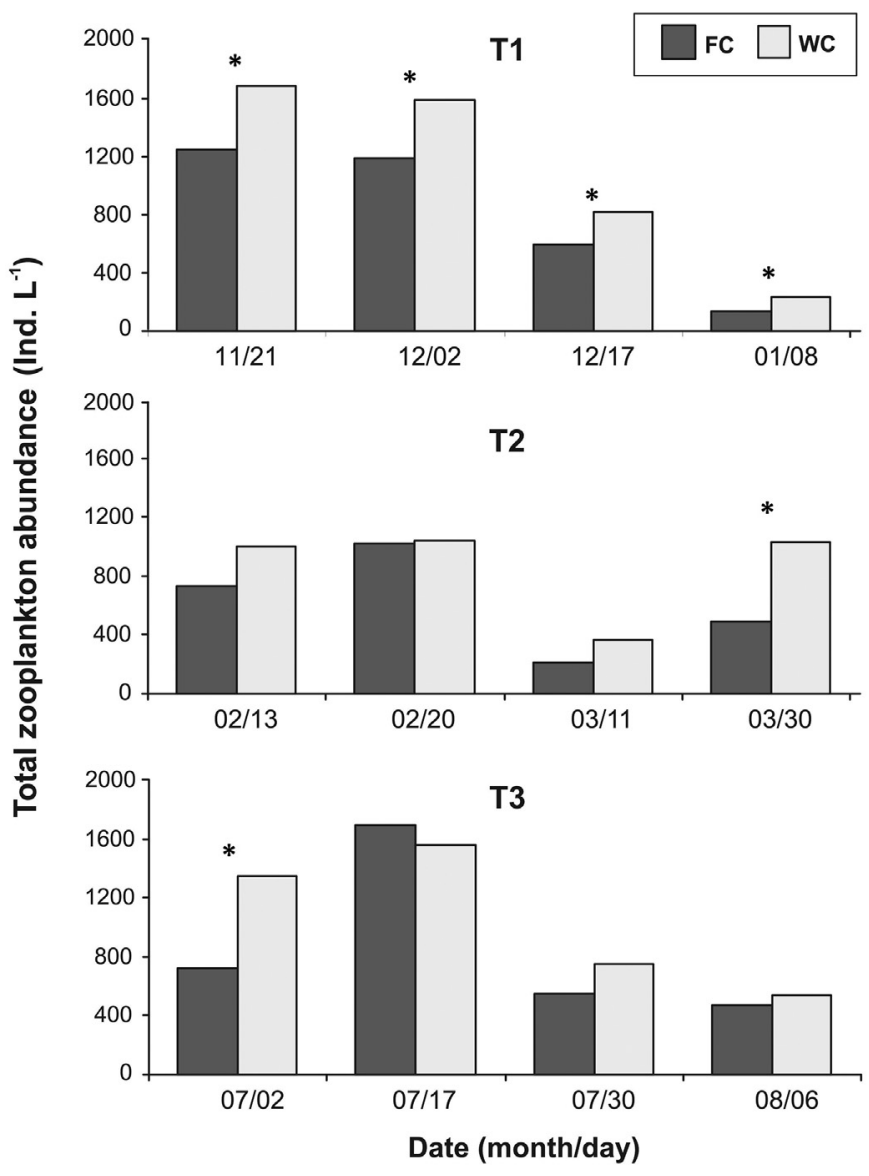

Fig. 4. Mean total zooplankton abundance found in cages with fish (FC) and cages without fish (WFC), for each sampling date. Significant differences for SNK test in zooplankton abundance between types of cage are indicated with asterisks.

each taxon observed in the zooplankton samples taken from the environment in relation to the total number of zooplankton individuals counted in these samples.

This index can take values from 0 to $+\infty$, where $F R=0$ indicates that available zooplankter is not part of the diet, FR from 0 to 1 suggests a negative selectivity, FR $=1$ an indifferent or neutral response and FR $>1$ represents a positive selectivity.

\subsubsection{Growth, survival and production of cultured pejerrey}

Fish length and weight were compared by repeated measures twoway analysis of variance (RM ANOVA) (Sokal and Rohlf, 1995;
Ruohonen, 1998; Quinn and Keough, 2002). This analysis tested the effects of the time, of the season, and of the interaction between those two factors over the period of pejerrey growth. These comparisons were made firstly among the cages of the same trial and secondly between trials. In the cases where there was no difference between cages, the entire pool of sampled lengths for each date was used to search for differences between seasons. When differences among cages arose, mean total length per cage was used. After the RM ANOVA, Bonferroni post-hoc tests were carried out to evaluate the differences in growth at each sampling date.

The specific growth rates (SGR) (Weatherley and Gill, 1987; Hopkins, 1992) of reared fish were calculated using the measurements obtained for TL (SGRL) and W (SGRW), as follows:

$\operatorname{SGRL}\left(\mathrm{cm} \mathrm{day}^{-} 1\right)=\left(\ln \mathrm{TL}_{2}-\ln \mathrm{TL}_{1}\right) /\left(\mathrm{t}_{2}-\mathrm{t}_{1}\right)$

where $\mathrm{TL}_{2}$ and $\mathrm{TL}_{1}$ are the mean total lengths at time $2\left(\mathrm{t}_{2}\right)$ and at time 1 $\left(t_{1}\right)$, respectively.

$\operatorname{SGRW}\left(\right.$ g day $\left.^{-} 1\right)=\left(\ln \mathrm{W}_{2}-\ln \mathrm{W}_{1}\right) /\left(\mathrm{t}_{2}-\mathrm{t}_{1}\right)$

where $W_{2}$ and $W_{1}$ are the mean total weight at $t_{2}$ and at $t_{1}$, respectively.

The mean survival rate percent (S\%) and mean final biomass per cage (B) were calculated using the $\mathrm{O}^{\prime}$ Conell and Raymond equation (Fex de Santis, 1991):

$\mathrm{S} \%=\{[(\mathrm{Lc} / \mathrm{K})+\mathrm{Sf}] / \mathrm{Ls}\} \times 100$

where Lc is the number of fish slaughtered in the samples, Sf the final fish number (at the end of the experiment), Ls the initial fish number and $\mathrm{K}$ a constant equal to $\mathrm{Sf} / 100$.

$\mathrm{B}(\mathrm{g})=\mathrm{M}_{\mathrm{fw}} \times \mathrm{N}_{\mathrm{f}}$

where $\mathrm{M}_{\mathrm{fw}}$ and $\mathrm{N}_{\mathrm{f}}$ are the mean final individual fish weight and the final number of fish, respectively.

Moreover, SGRL and SGRW for each fish sampling period, as dependent variables, were regressed against the observed values of different independent variables to evaluate the relationship between these variables using multiple regressions (Sokal and Rohlf, 1995). The independent variables chosen were mean lake temperature, mean zooplankton dry weight in the lake, mean zooplankton abundance in the lake, gut contents as a percentage of the different size classes (I, II and III) and mean growth in length and in weight, as mean values by sampling date.

The significance level used in all performed statistical tests was $\mathrm{p} \leq 0.05$.

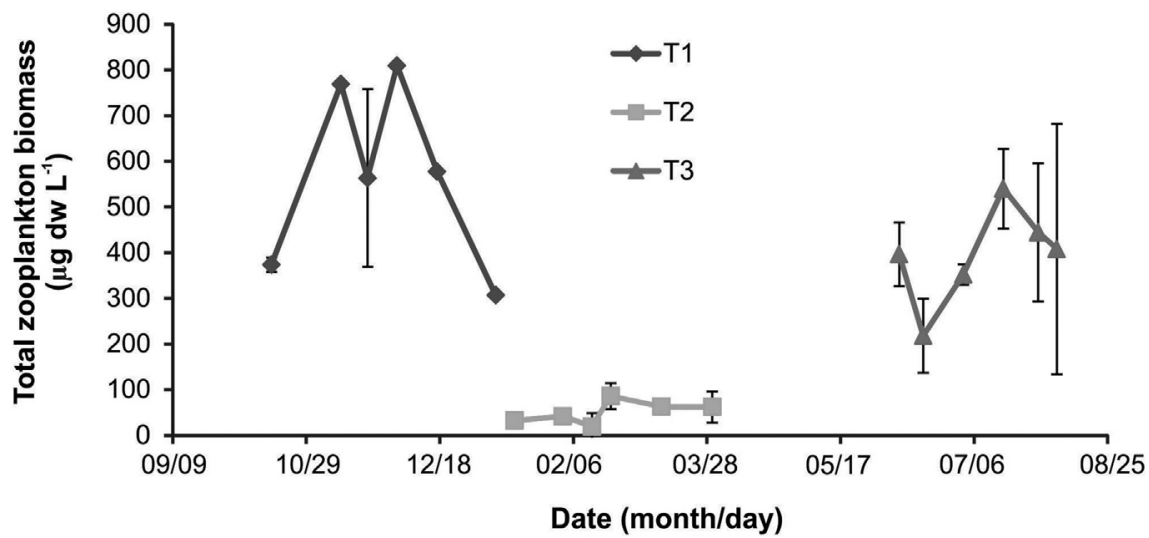

Fig. 5. Total zooplankton biomass (means and standard deviations), registered in the lake throughout the experimental period. 


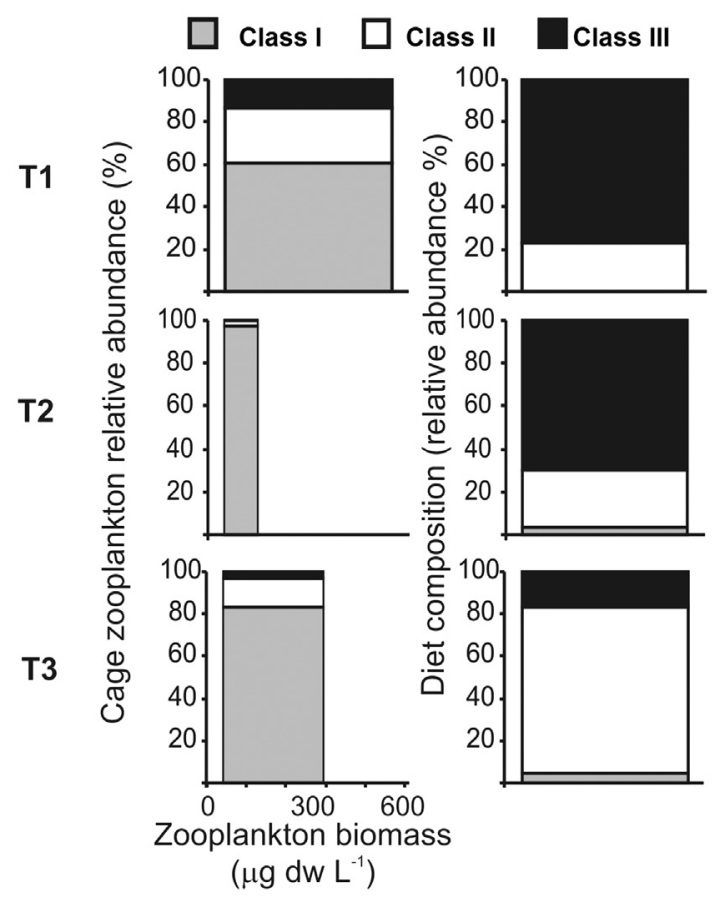

Fig. 6. Cage zooplankton abundance and biomass for each experiment, by zooplankton size class (columns at the left, $\mathrm{x}$ and $\mathrm{y}$ axis, respectively). Diet compositions are expressed as percentual abundance by size class (columns at the right). Differences in the three trials (ANOSIM, $\mathrm{p}<0.05$ ) were observed.

\section{Results}

\subsection{Physicochemical parameters}

The hydrometric level decreased throughout the experiment, from an average of $1.54 \mathrm{~m}$ in spring (T1) to $0.95 \mathrm{~m}$ in autumn (T3), while the conductivity and $\mathrm{pH}$ changed in an opposite way. Transparency was higher in summer (T2), whereas dissolved oxygen showed its minimum value during the same season (Table 1). Meanwhile, temperature followed a seasonal pattern, showing an increasing trend during spring, maximum and relatively stable values during summer and a decreasing pattern during the autumn, when the lowest levels were recorded (Fig. 2).

\subsection{Zooplankton community}

Lake zooplankton abundance varied seasonally, with a maximum mean value during summer. The taxonomic composition presented some differences among the three seasons: cladocerans were abundant during spring but almost absent during the other seasons, while rotifers and nauplii larvae were dominant in nearly all cases (Fig. 3). Calanoid copepods were absent during almost the entire experiment, with the exception of one sampling date in T3 (autumn), but even then were present in very low abundance. Lake zooplankton species abundance
Table 4

Foraging rate food selectivity index (FR) by fish age for the three trials.

\begin{tabular}{lllll}
\hline Trial & Age (days) & FR I & FR II & FR III \\
\hline 1 & 46 & 0.2 & 1.5 & 9.7 \\
1 & 67 & 0.0 & 1.4 & 3.5 \\
1 & 82 & 0.0 & 0.4 & 6.9 \\
1 & 104 & 0.0 & 0.9 & 47.7 \\
2 & 49 & 0.5 & 372.7 & 27.6 \\
2 & 64 & 0.0 & 3.9 & 11.2 \\
2 & 83 & 0.0 & 1.0 & 46.8 \\
2 & 104 & 0.1 & 1.9 & 295.2 \\
3 & 69 & 0.2 & 9.8 & 2.6 \\
3 & 84 & 0.4 & 5.5 & 13.2 \\
3 & 104 & 0.0 & 5.4 & 6.4 \\
\hline
\end{tabular}

was different between seasons (ANOSIM, $\mathrm{R}=0.69, \mathrm{p}<0.05$ ), with discriminant species identified by SIMPER different in each pair-wise comparison (Table 2).

Total zooplankton abundance found in WFC was higher than that registered in FC on average (Fig. 4). An interaction between the factors "time" and "type of cage" (WFC or FC) was found in T1 and T2 (RMANOVA, $\mathrm{F}_{(3,6)}=28.2 ; \mathrm{p}<0.05$, in $\mathrm{T} 1$ and $\mathrm{F}_{(3,12)}=4.1 ; \mathrm{p}<0.05$, in $\mathrm{T} 2$ ). In T3, zooplankton abundance differed among cage types (RM ANOVA, $\left.\mathrm{F}_{(1,2)}=29.8 ; \mathrm{p}<0.05\right)$. The SNK test indicated that the zooplankton abundance found in WFC was higher than that in FC $(\mathrm{p}<0.05)$ for all spring sampling dates, the last sampling date in summer and the first one in autumn. However, no differences in species composition or species dominance among WFC and FC were detected (ANOSIM, p > 0.05), indicating that the differences among these treatments were quantitative in nature.

The lake zooplankton biomass was different among seasons (Fig. 5). The maximum mean value was found in spring $(566.40 \pm 35.04 \mu \mathrm{g}$ dry weight $\left.\mathrm{L}^{-1}\right)$. The minimum was found in summer $(50.65 \pm 19.00 \mu \mathrm{g}$ dry weight $\mathrm{L}^{-1}$ ). In autumn, the mean zooplankton biomass was $393.07 \pm$ $114.26 \mu$ dry weight $\mathrm{L}^{-1}$.

Zooplankton species biomass differed among seasons (ANOSIM, $\mathrm{p}<0.05$ ), with the discriminant species being the cladocerans Ceriodaphnia cf. dubia and Bosmina huaronensis for higher biomass in T1 than T2 and T3, and copepods Acanthocyclops robustus and Metacyclops mendocinus for larger values in T3 as compared to T2 (SIMPER).

\subsection{Feeding cultured pejerrey}

Juvenile pejerrey fed mostly on zooplankton of size III during spring and summer, especially after 69 days of life. In autumn, the diet was composed mainly of zooplankton size II (Fig. 6). When comparing the zooplankton supply in terms of proportions of abundance per species per cage with the proportions of intake, differences in the three trials were observed (ANOSIM, $\mathrm{p}<0.05$ ), with different discriminating species (SIMPER) (Table 3).

The FR index results indicated that the fish were selective toward medium-sized zooplankton at T2 and T3, then selected the larger size (III) with advancing age (Table 4).

Table 3

SIMPER results when cage zooplankton abundance is compared with the zooplankton ingested by pejerrey juveniles reared in the three trials.

\begin{tabular}{|c|c|c|c|}
\hline & $\mathrm{T} 1$ & $\mathrm{~T} 2$ & T3 \\
\hline Dissimilarity (\%) & 75.9 & 93.5 & 84.6 \\
\hline $\begin{array}{l}\text { Discriminant species (Higher } \\
\text { abundance in gut contents) }\end{array}$ & $\begin{array}{l}\text { Juveniles and adults of } \\
\text { Acanthocyclops robustus }\end{array}$ & Juveniles of $A$. robustus & $\begin{array}{l}\text { Metacyclops mendocinus and } \\
\text { Bosmina huaronensis }\end{array}$ \\
\hline $\begin{array}{l}\text { Discriminant species (Higher } \\
\text { abundance in the lake) }\end{array}$ & Nauplii larvae & $\begin{array}{l}\text { Brachionus havanaensis } \\
\text { and nauplii larvae }\end{array}$ & $\begin{array}{l}\text { Nauplii larvae, Keratella tropica } \\
\text { and K. lenzi }\end{array}$ \\
\hline
\end{tabular}

\footnotetext{
a Only species contributing $>10 \%$ of overall dissimilarity are reported.
} 


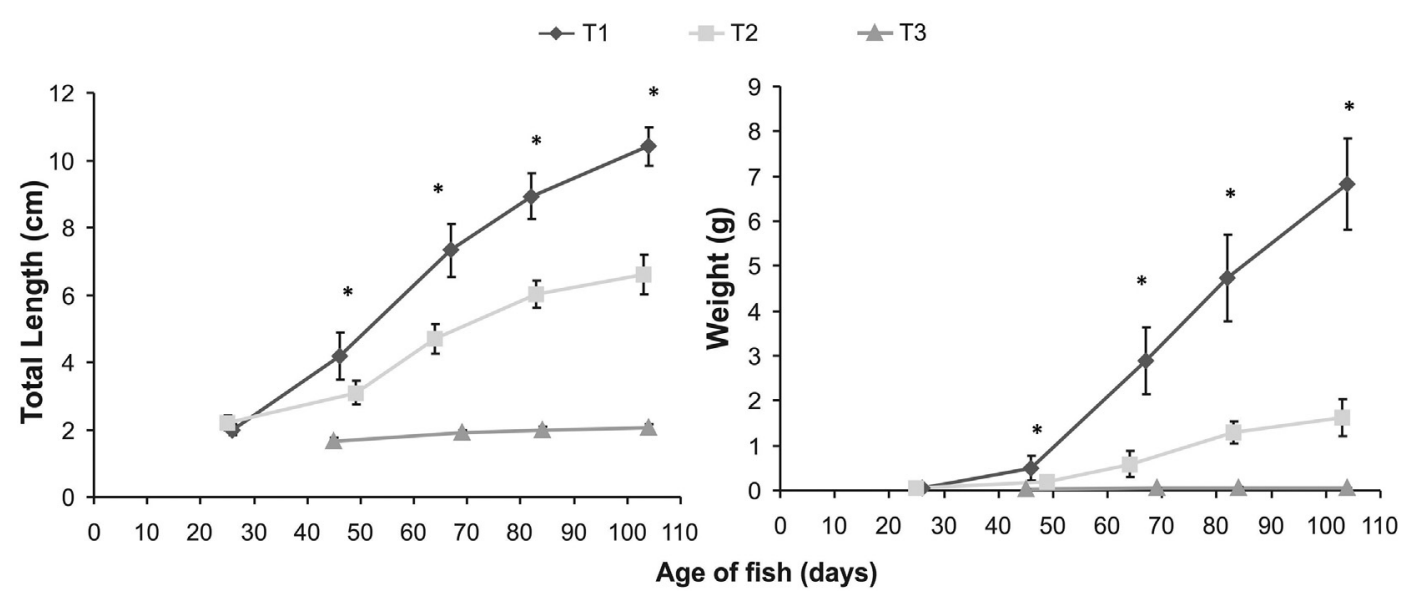

Fig. 7. Average growth in length $(\mathrm{cm})$ and weight $(\mathrm{g})$ and standard deviations of pejerrey reared in cages for each age of fish (days) corresponding with each sampling date. Significant differences between trials are indicated with asterisks.

\subsection{Pejerrey growth, production and survival}

The pejerrey growth in length and weight was not different among the replicated cages in $\mathrm{T} 1$ and $\mathrm{T} 3$, while $\mathrm{T} 2$ presented an interaction between "time" and "cage" (RM ANOVA, $\mathrm{F}_{(2,116)}=5.15 ; \mathrm{p}<0.05$ and $\mathrm{F}_{(2,36)}=5.0 ; \mathrm{p}<0.05$, for length and weight, respectively). However, according to the Bonferroni test, this interaction was significant $(\mathrm{p}<0.05)$ only at the end of the trial (104 days-old). Growth in terms of length and weight was different between trials (RM ANOVA, $\mathrm{F}_{(4262)}=162.9$; $\mathrm{p}<0.05$ and $\mathrm{F}_{(4,94)}=69.9 ; \mathrm{p}<0.05$, respectively). The bigger fish were obtained in T1 (spring) with a final weight eight times higher than that obtained in summer and fifty times greater than that obtained in autumn (Fig. 7).

These differences were also observed for growth rates and final biomass (Table 5).

The production obtained at the end of the spring trial was one and two orders of magnitude higher than that of summer and autumn, respectively, while survival was higher in one of the T2 cages, followed by the $\mathrm{T} 1$ cages (Table 5 ).

Multiple linear regression analysis selected the mean growth in weight $(\mathrm{W})$, the mean lake temperature $(\mathrm{T})$ and the gut contents as a percentage of size class III (GCIII) $\left(\mathrm{R}^{2}=0.78 ; \mathrm{n}=22 ; \mathrm{F}=11.57\right.$; $\mathrm{p} \leq 0.05$, in length and $\mathrm{R}^{2}=0.81 ; \mathrm{n}=22 ; \mathrm{F}=13.75 ; \mathrm{p} \leq 0.05$, in weight), as significant independent predictor variables that account for SGR variation. The fitted models are detailed below:

SGRL $=-0.024+-0.009 \mathrm{~W}+0.0023 \mathrm{~T}+0.0004 \mathrm{GCIII}$

SGRW $=-0.076+-0.03 \mathrm{~W}+0.007 \mathrm{~T}+0.0013 \mathrm{GCIII}$

Table 5

Mean specific growth rates in length and weight (SGRL, $\mathrm{cm}$ day $^{-1}$ and SGRW, $\mathrm{g} \mathrm{day}^{-1}$, respectively), survival rate (\%) and final biomass ( $\mathrm{g}$ ) for each cage and experiment. Significant differences $(\mathrm{p}<0.05)$ among cages are indicated in superscript letters.

\begin{tabular}{llllll}
\hline Trial & Cage & $\begin{array}{l}\text { SGRL } \\
\left(\mathrm{cm} \mathrm{day}{ }^{-1}\right)\end{array}$ & $\begin{array}{l}\text { SGRW } \\
\left(\mathrm{g} \mathrm{day}^{-1}\right)\end{array}$ & $\begin{array}{l}\text { Survival rate } \\
(\%)\end{array}$ & $\begin{array}{l}\text { Final biomass } \\
(\mathrm{g})\end{array}$ \\
\hline 1 & $\mathrm{~A}$ & $0.021^{\mathrm{a}}$ & $0.064^{\mathrm{a}}$ & $82.0^{\mathrm{a}}$ & $2764.0^{\mathrm{a}}$ \\
1 & $\mathrm{~B}$ & $0.021^{\mathrm{a}}$ & $0.063^{\mathrm{a}}$ & $85.7^{\mathrm{a}}$ & $2893.7^{\mathrm{a}}$ \\
2 & $\mathrm{~A}$ & $0.016^{\mathrm{b}}$ & $0.046^{\mathrm{b}}$ & $70.2^{\mathrm{a}}$ & $562.4^{\mathrm{b}}$ \\
2 & $\mathrm{~B}$ & $0.014^{\mathrm{b}}$ & $0.041^{\mathrm{b}}$ & $99.6^{\mathrm{a}}$ & $805.2^{\mathrm{b}}$ \\
3 & $\mathrm{~A}$ & $0.004^{\mathrm{c}}$ & $0.018^{\mathrm{c}}$ & $43.3^{\mathrm{a}}$ & $10.4^{\mathrm{c}}$ \\
3 & $\mathrm{~B}$ & $0.004^{\mathrm{c}}$ & $0.020^{\mathrm{c}}$ & $43.3^{\mathrm{a}}$ & $10.4^{\mathrm{c}}$ \\
\hline
\end{tabular}

\section{Discussion}

Colautti et al. (2010) showed for the first time that extensive cage culture could be implemented to obtain pejerrey of at least one year old. As a suggestion for future studies the authors remarked the need to develop guidelines to apply in a more accurate way the culture technique and optimize it, considering its dependence to environmental conditions. In this sense, Garcia de Souza et al. (2015) explored the effects of zooplankton availability and density of rearing over pejerrey culture performance, while the present study evaluates for the first time the effects of seasonality over the system. Thus, this work represents a contribution to developing concepts and criteria to implement an ecosystem-based approach to the aquaculture of a South American native species inhabiting highly productive shallow lakes. The results confirm that Pampean lakes could be suitable environments to support pejerrey ecological aquaculture systems by taking advantage of their high natural productivity and secondary production dynamics. This suitability for ecological aquaculture implementation is also enhanced by the lack of aquaculture tradition in Argentina, which limits the availability of facilities and specialized technicians to carry out intensive culture methods.

The implementation of this kind of systems requires the use of natural secondary production, which highlights the role of seasonal zooplankton structure variations on pejerrey culture performance in extensive cage culture. The zooplankton assemblage structure was different among the three evaluated seasons, and the highest pejerrey growth was achieved during spring, when zooplankton biomass was maximal in the lake. Accordingly, better growth rates and production of juvenile pejerrey were obtained with higher lake zooplankton dry weight and greater representation of size class III individuals (copepods and cladocerans of $>0.7 \mathrm{~mm}$ in mean length). For instance, specimens of Ceriodaphnia are considered as one of the heaviest and more nutritious zooplankton component (Morris and Mischke, 1999); C. cf. dubia was identified as a discriminant species during spring. This season was also the most stable in terms of zooplankton abundance; however, during summer and autumn, it was possible to observe two maximum values preceded and followed by low zooplankton abundance (Fig. 3).

The multiple regression results support the inference that seasonal temperature and zooplankton variations have significant effects on pejerrey growth in floating cages, whereas mean lake temperature and the amount of zooplankton of size III consumed are the main influencing factors. This finding partially agrees with those reported by Colautti et al. (2010), who found that during the coldest months in another Pampean lake (Lacombe), the growth of pejerrey cultured in floating cages was temporarily enhanced due to peaks in the biomass of calanoid copepods (zooplankton size III). 
Pejerrey exhibited selective feeding habits during the entire experiment, as was shown by the FR index results (Table 4). Zooplankton of size III was the main food since the beginning of T1 (46 days-old), while in T2 size III organisms became the main food consumed after 69 days; in T3, this consumption of zooplankton of size III did not happen prior to the end of the trial (Fig. 6). It is important to note that in $\mathrm{T} 1$ and T2, zooplankton size III became the main food when fish reached around $4 \mathrm{~cm}$ in length. This length is almost twice as large as the final length of T3 fish. Therefore, the contribution of different zooplankton size classes to the gut contents was related to both food availability and fish size. The access to zooplankton size III appears to be a critical factor for promoting better growth performance. Thus, taking into account the quality of offered and consumed zooplankton in the experiment, it is clear that autumn does not meet the necessary conditions for an efficient beginning of extensive ecological cage culture of pejerrey.

This study also demonstrates that better growth rates and survival were obtained when fish consumed mainly large zooplankton. This preference could be due to a better efficiency in the energetic balance (Portella et al., 1997; Atencio-García et al., 2003b), and was also registered for other planktivorous fish (Zaret, 1980; Mageed and Konsowa, 2002). In particular, larvae and juveniles of freshwater neotropical species, such as Brycon siebenthalae (Yamú), Prochilodus magdalenae (Bocachico), Piaractus mesopotamicus (Pacú), Colossoma macropomum (Tambaqui) and Prochilodus scrofa (Curimba) (Atencio-García et al., 2003a; Atencio-García et al., 2003b; Fregadolli, 1990; Pelli et al., 1996) have high selectivity toward cladocerans and copepods and an insignificant intake of rotifers and protozoa (Prieto Guevara and AtencioGarcía, 2008).

Selective feeding of pejerrey also has effects on the zooplankton assemblage structure, as was shown by the average size reduction in FC and differences in species composition between treatments. In this sense, the main effect of pejerrey planktivory was the drastic reduction in cladocerans in FC, the abundance of which remained high in WFC. Therefore, the zooplankton biomass found in WFC was always higher than in FC, which is coincident with the "size efficiency" hypothesis, which postulates that zooplankton mean size tends to be maximum when the density of vertebrate predators is low. If the density of vertebrate predators increases, average zooplankton size decreases (Brooks and Dodson, 1965). The results are also in agreement with the matchmismatch hypothesis, because food availability, which fluctuates seasonally together with fish size, determines accessibility to the different sizes of prey.

\section{Conclusions}

This study contributes to a better understanding of the functional link between pejerrey and zooplankton structure in Pampean shallow lakes and its relationship with seasonality, providing criteria and guidelines to improve the performance of an ecosystem-based extensive cage culture. Furthermore, La Salada de Monasterio Lake has limnological characteristics and a zooplankton community similar to those of other Pampean shallow lakes (Claps et al., 2004; Colautti et al., 2010; Diovisalvi et al., 2010), which suggests that this culture method could be applied in other shallow lakes of this region. In the case of cage aquaculture, it is important to evaluate seasonal variations in zooplankton quantity and quality prior to stocking the cages to maximize the growth and survival of fish. In the same way, this assessment would allow researchers and farmers to determine suitable stocking density to optimize the use of available resources (Garcia de Souza et al., 2015).

Finally, another feature that emerges from this study is the importance of monitoring the culture process by assessing, not only the lake zooplankton, but also the gut contents of cultured individuals, at least fortnightly. This will make it possible to know what is being effectively consumed. The relevance of this observation is supported by the results of T2 when zooplankton size III was poorly represented in the lake but instead was detected in high proportions at gut contents, resulting in intermediate growth rates. This practice should be considered as part of the guidelines to maximize the efficiency of pejerrey cage culture. According to Costa-Pierce and Page (2012), it would be possible to carry out an adaptive management of culture systems, based on the ecosystem, and it would be the key for the development of an ecological aquaculture (ecosystem-based) for pejerrey.

\section{Acknowledgements}

We thank G. Berasain and C. Velasco for providing pejerrey larvae and S. Sampietro for permission to use the La Salada de Monasterio Lake facilities and for her assistance throughout the experiment. We also acknowledge the collaboration of Dra. González Sagrario, who improved the statistical approach. This work was supported by PICT 2010 No. 1579 ANPCyT and PIP No. 0259 CONICET. This paper is Scientific Contribution No. 986 to the Institute of Limnology "Dr. Raúl A. Ringuelet" (ILPLA, CONICET, UNLP).

\section{References}

APHA, 1995. Standard Methods for Analysis of Water and Wastewater. nineteenth ed American Public Health Association, Washington DC.

Atencio-García, V.J., Kerguelen, E., Wadnipar, L., Narvaez, A., 2003a. Manejo de la primera alimentación del bocachico (Prochilodus magdalenae). 8 (1). Revista MVZ Córdoba, pp. 254-260.

Atencio-García, V.J., Zaniboni-Filho, E., Pardo-Carrasco, S.C., Arias-Castellanos, A., 2003b. Influência da primeira alimentação na larvicultura e alevinagem do yamú Brycon siebenthalae (Characidae). Maringá, Brasil. Acta Sci: Anim. Sci. 25 (1), 61-72.

Baigún, C.R.M., Anderson, R.O., 1994. The use of structural indices for the management of pejerrey (Odontesthes bonariensis, Atherinidae) in Argentine lakes. N. Am. Fish. Manag. 13, 600-608.

Benítez, H.H., Claps, M.C., 2000. Zooplancton de una laguna pampásica (Monte) y su afluente (El Totoral). Caracterización estructural en un ciclo anual. Diversidad y Ambiente. 1 pp. 87-96.

Berasain, G.E., Colautti, D.C., Lenicov, M.R., Argemi, F., Bohn, V.Y., Miranda, L.A., 2015. Impact of water salinity on Odontesthes bonariensis (Actinopterygii, Atherinopsidae) fisheries in Chasicó Lake (Argentina). Hydrobiologia 752 (1), 167-174.

Beveridge, M.C.M., 2004. Cage Aquaculture. third ed. Blackwell Publishing, Oxford.

Bottrell, H.H., Duncan, A., Gliwicz, Z.M., Grygierek, E., Herzig, A., Hillbricht-Ilkowska, A. Kurasawa, H., Larsson, P., Weglenska, T., 1976. A review of some problems in zooplankton production studies. Nor. J. Zoo. 24, 419-456.

Brooks, J.L., Dodson, S.L., 1965. Predation, body size, and composition of plankton. Science 150, 28-35.

Claps, M.C., Gabellone, N.A., Benítez, H.H., 2004. Zooplankton biomass in an eutrophic shallow lake (Buenos Aires, Argentina): spatio-temporal variations. Ann. Limnol. Int. J. Limnol. 40, 201-210.

Clarke, K.R., Warwick, R.M., 2001. Change in Marine Communities: An Approach to Statistical Analysis and Interpretation. second ed. PRIMER-E, Plymouth.

Colautti, D.C., Remes Lenicov, M., Berasain, G., 2003. Vulnerabilidad del pejerrey Odontesthes bonariensis a la pesca deportiva en función de su condición. Biología Acuática 20, 49-55.

Colautti, D.C., Garcia de Souza, J.R., Miranda, L., 2009. Sistema de cultivo mixto en jaulas y estanques para el pejerrey Odontesthes bonariensis. Biología Acuática 26, 47-54.

Colautti, D.C., Garcia de Souza, J.R., Balboni, L., Baigún, C.R.M., 2010. Extensive cage culture of pejerrey (Odontesthes bonariensis) in a shallow Pampean lake in Argentina. Aquac. Res. 41, 376-384.

Costa-Pierce, B.A., 2002. Sustainability of cage aquaculture ecosystems for large-scale resettlement from hydropower dams: an Indonesian case study. In: Costa-Pierce, B.A. (Ed.), Ecological Aquaculture: The Evolution of the Blue Revolution. Blackwell, Oxford, pp. 286-313.

Costa-Pierce, B.A., Page, G.G., 2012. Sustainability science in aquaculture. In: Costa-Pierce, B.A. (Ed.), Ocean Farming and Sustainable Aquaculture Science and Technology. Encyclopedia of Sustainability Science and Technology. Springer Science, New York, pp. $564-581$.

Cushing, D.H., 1972. The production cycle and the numbers of marine fish. In: Edwards, R.W., Garrod, D.J. (Eds.), Conservation and Productivity of Natural Waters. Pergamon Press, Oxford, pp. 213-232.

Cushing, D.H., 1990. Plankton production and year-class strength in fish populations: an update of the match/mismatch hypothesis. Adv. Mar. Biol. 26, 250-293.

Destefanis, S., Freyre, L., 1972. Relaciones tróficas de los peces de la laguna de Chascomús con un intento de referenciación ecológica y tratamiento bioestadístico del espectro trófico. Acta Zoológica Lilloana XXIX.

Diovisalvi, N., Berasain, G., Unrein, F., Colautti, D., Fermani, P., Llames, M., Torremorell, A. Lagomarsino, L., Pérez, G., Escaray, R., Bustingorry, J., Ferraro, M., Zagarese, H., 2010 Chascomús: estructura y funcionamiento de una laguna pampeana turbia. Ecología Austral. 20, 115-127.

Diovisalvi, N., Bohn, V.Y., Piccolo, M.C., Perillo, G.M.E., Baigún, C.R.M., Zagarese, H.E., 2015a Shallow lakes from the Central Plains of Argentina: an overview and worldwide comparative analysis of their basic limnological features. Hydrobiologia 752, 5-20. 
Diovisalvi, N., Salcedo Echeverry, G.E., Lagomarsino, L., Zagarese, H.E., 2015b. Seasonal patterns and responses to an extreme climate event of rotifers community in a shallow eutrophic Pampean lake. Hydrobiologia 752, 125-137.

Dumont, H.J., Van De Velde, I., Dumont, S., 1975. The dry weight estimate of biomass in selection of Cladocera, Copepoda and Rotifera from the plankton, periphyton and benthos of continental waters. Oecologia (Berl.) 19, 75-97.

Elisio, M., Chalde, T., Miranda, L.A., 2012. Effects of short periods of warm water fluctuations on reproductive endocrine axis of the pejerrey (Odontesthes bonariensis) spawning. Comp. Biochem. Physiol. A 163 (1), 47-55.

Elisio, M., Chalde, T., Miranda, L.A., 2015. Seasonal changes and endocrine regulation of pejerrey (Odontesthes bonariensis) spermatogenesis in the wild. Gen. Comp. Endocrinol. 221, 236-243.

Escalante, A.H., 2001. Alimentación natural del pejerrey. In: Grosman, F. (Ed.), Fundamentos biológicos, económicos y sociales para la correcta gestión del recurso pejerrey. Editorial Astyanax, Azul, pp. 67-75.

Fex de Santis, R., 1991. Crecimiento y sobrevivencia de larvas de cachama (Colossoma macropomum) con alimento vivo y no vivo. Bol. Red. Acuic. 5 (2), 9-12.

Fregadolli, C.H., 1990. Estudo comparativo do comportamento alimentar de larvas de pacu Piaractus mesopotamicus (Holmberg, 1887) e Tambaqui Colossoma macropomum (Cuvier, 1818) em laboratório. (Dissertação. Tesis de Maestria). Universidade Federal da Bahia, Salvador BA.

Freyre, L.R. Colautti, D.C., Maroñas, M.E, Sendra, E.D. Remes Lenicov, M., 2009. Seasona changes in the somatic indices of the freshwater silverside, Odontesthes bonariensis (Teleostei, Atheriniformes) from a Neotropical shallow lake (Argentina). Braz. J. Biol. 69 (2), 389-395.

Gannon, J.E., 1971. Two counting cells for the enumeration of zooplankton microcrustacea. Trans. Am. Microsc. Soc. 90, 486-490.

Garcia de Souza, J.R., Solimano, P.J., Maiztegui, T., Baigún, C.R.M., Colautti, D.C., 2015. Effects of stocking density and natural food availability on the extensive cage culture of pejerrey (Odontesthes bonariensis) in a shallow Pampean lake in Argentina. Aquac. Res. 46, 1332-1344.

González Sagrario, M.A., Balseiro, E., Ituarte, R., Spivak, E., 2009. Macrophytes as refuge o risky area for zooplankton: a balance set by littoral predacious macroinvertebrates. Freshw. Biol. 54, 1042-1053.

Hambrey, J., Edwards, P., Belton, B., 2008. An ecosystem approach to freshwater aquaculture: a global review. In: Soto, D., Aguilar-Manjarrez, J. Hishamunda, N. (Eds.), Building an Ecosystem Approach to Aquaculture. FAO Fisheries and Aquaculture ProceedingsNo 14. FAO, Rome, pp. 117-221.

Hjort, J., 1914. Fluctuations in the great fisheries of northern Europe reviewed in the light of biological research. Rapp. P.-V. Réun. Cons. Int. Explor. Mer. 20, 1-228.

Hopkins, K.D., 1992. Reporting fish growth: a review of the basics. J. World Aquacult. Soc. 23 (3), 173-179.

Lagomarsino, L., Pérez, G.L., Escaray, R., Bustingorry, J., Zagarese, H.E., 2011. Weather variables as drivers of seasonal phosphorus dynamics in a shallow hypertrophic lake (Laguna Chascomús, Argentina). Fundam. Appl. Limnol. 178, 191-201.

Lawrence, S.G., Malley, D.F., Findlay, W.J., Maciver, M.A., Delbaere, I.L., 1987. Method for estimating dry weight of freshwater planktonic crustaceans from measures of length and shape. Can. J. Fish. Aquat. Sci. 44, 267-274.

Le Cren, E.D., Lowe-McConnell, R.H., 1980. The Functioning of Freshwater Ecosystems. Cambridge Univ, Press, Cambridge.

Little, D., Muir, J., 1987. A Guide to Integrated Warm Water Aquaculture. Insitute of Aquaculture Publications, University of Stirling, Scotland.

Mageed, A.A., Konsowa, A.H., 2002. Relationship between phytoplankton, zooplankton, and fish cultures in a freshwater fish farm. Egypt. J. Aquat. Biol. Fish. 6 (2), 183-206.

McCauley, E., 1984. The estimation of the abundance and biomass of zooplankton in samples. In: Downing, R. (Ed.), A Manual on Methods for the Assessment of Secondary Productivity in Fresh Waters, IBP 17. Blackwell Scientific Publications, Oxford, pp. 228-265.

Miranda, L.A., Berasain, G.E., Velasco, C.A.M., Shirojo, Y., Somoza, G.M., 2006. Natura spawning and intensive culture of pejerrey Odontesthes bonariensis juveniles. Biocel 30, 157-162.
Morris, J.E., Mischke, C.C., 1999. Plankton Management for Fish Culture Ponds. Tech. Bull. Ser. (Ames, Iowa No. 114)

OECD, 1982. Eutrophication of waters. Monitoring, Assessment and Control. OECD, París.

Pelli, A., Dumont-Neto, R., Silva, J., Gonçalves, S., Souza, D., Barbosa, N., 1996. Início de ingestão de ração por pacú (Piaractus mesopotamicus Holmberg 1887), curimba (Prochilodus scrofa Steinchdacner, 1881) e piau (Leporinus friderici Bloch, 1794). Em condições de criação semi-intensiva. Memorias de Simpósio Brasileiro de Aqüicultura. 9, p. 88

Pérez, G.L., Llames, M.E., Lagomarsino, L., Zagarese, H.E., 2011. Seasonal variability of optical properties in a highly turbid lake (Laguna Chascomús, Argentina). Photochem. Photobiol. 87, 659-670.

Portella, M.C., Cestarolli, M.A., Verani, J.R., Rojas, N.E., 1997. Produção de organismos planctónicos para alimentação inicial de larvas de peixes de agua doce. Boletim do Instituto do Pesca 24, 79-89.

Prieto Guevara, M.J., Atencio-García, V.J., 2008. Zooplancton en la larvicultura de peces neotropicales. Rev. MVZ Córd. 13 (2), 1415-1425.

Prieto Guevara, M.J., Rosa Logato, P.V., Ferreira de Moraes, G., Del Okamura Guedes de Araújo, F., 2006. Tipo de alimento, sobrevivência e desempenho inicial de Pós-larvas de pacu (Piaractus mesopotamicus). Larvas-Brasil: Ciência Agrotecnologica 30 (5), $1002-1007$

Quinn, G., Keough, M., 2002. Experimental Design and Data Analysis for Biologists. Cambridge Univ, Press, Cambridge.

Quirós, R., Drago, E., 1999. The environmental state of Argentinean lakes: an overview. Lakes Reserv. Res. Manag. 4, 55-64.

Quirós, R., Rennella, A.M., Boveri, M.B., Rosso, J.J., Sosnovsky, A., 2002. Factores que afectan la estructura y el funcionamiento de las lagunas pampeanas. Ecología Austral 12, $175-185$.

Ringuelet, R.A., Iriart, R., Escalante, A., 1980. Alimentación del pejerrey (Basilichthys bonariensis bonariensis) en la laguna de Chascomús (Buenos Aires, Argentina). Relaciones ecológicas de complementación y eficiencia trófica del plancton. Limnobios 1, 447-460.

Ruohonen, K., 1998. Individual measurements and nested designs in aquaculture experiments: a simulation study. Aquaculture 165, 149-157.

Ruttner-Kolisko, A., 1977. Suggestions for biomass calculations of plankton rotifers. Arch. Hydrobiol. 8, 71-76.

Sokal, R.R., Rohlf, F.J., 1995. Biometry: The Principles and Practice of Statistics in Biological Research. third ed. Freeman, New York.

Solari, L., Claps, M., Gabellone, N., 2002. River backwater pond interactions in the lower basin of the Salado River (Buenos Aires, Argentina). Arch. Hydrobiol. Suppl. 141, $1-21$.

Solimano, P.J., Garcia de Souza, J.R., Maiztegui, T., Baigún, C.R.M., Colautti, D.C., 2015. New approaches for growth improvement in pejerrey Odontesthes bonariensis (Valenciennes, 1835) culture (Atherinomorpha: Atherinopsidae). Neotrop. Ichthyol. 13 (1), 213-220.

Somoza, G.M., Miranda, L.A., Berasain, G.E., Colautti, D., Remes Lenicov, M., Strüssmann, C.A., 2008. Historical aspects, current status and prospects of pejerrey aquaculture in South America. Aquac. Res. 39, 784-793.

Torremorell, A., Bustingorry, J., Escaray, R., Zagarese, H., 2007. Seasonal dynamics of a large, shallow lake, Laguna Chascomús: the role of light limitation and other physical variables. Limnologica 37 (1), 100-108.

Torremorell, A., Llames, M.E., Pérez, G.L., Escaray, R., Bustingorry, J., Zagarese, H., 2009. Annual patterns of phytoplankton density and primary production in a large, shallow lake: the central role of light. Freshw. Biol. 54, 437-449.

Velasco, C.A., Berasain, G.E., Ohashi, M., 2008. Producción intensiva de juveniles de pejerrey (Odontesthes bonariensis). Biología Acuática 24, 53-58.

Weatherley, A.H., Gill, H.S., 1987. The Biology of Fish Growth. Academic Press, London.

Zaret, T.M., 1980. Predation and Freshwater Communities. Yale Univ. Press, New Haven, Connecticut. 